\title{
Antibacterial Activities of Some Transition Metal Schiff Base Complexes
}

\author{
M. N. Islam ${ }^{1, *}$, S. M. S. Shahriar ${ }^{2}$, M. K. Islam ${ }^{3}$, M. Jesmin ${ }^{3}$, \\ M. M. $\mathrm{Ali}^{3}$, J. A. Khanam ${ }^{4}$ \\ ${ }^{1}$ Department of Applied \& Environmental Chemistry, University of Chittagong, \\ Chittagong - 4331, Bangladesh. \\ ${ }^{2}$ Department of Applied Chemistry and Chemical Technology, Faculty of Food Science and \\ Technology, Chittagong Veterinary and Animal Sciences University, \\ Chittagong - 4202, Bangladesh. \\ ${ }^{3}$ Department of Applied Chemistry and Chemical Engineering, University of Rajshahi, \\ Rajshahi - 6205, Bangladesh. \\ ${ }^{4}$ Department of Biochemistry and Molecular Biology, University of Rajshahi, \\ Rajshahi - 6205, Bangladesh. \\ *E-mail address: mnazrulacct@gmail.com
}

\begin{abstract}
A new series of four transition metal complexes of a Schiff base derived from salicylaldehyde and glycine, viz. [N-salicylidene glycinato diaqua cobalt (II) dimer] (SGCo) $2, \quad[\mathrm{~N}-$ salicylideneglycinato-di-aqua-nickel(11)dimer $] \quad(\mathrm{SGN})_{2}, \quad$ [N-salicylideneglycinato-aqua-copper(II)] (SGC) and [N-salicylidene glycinato diaqua zinc(II) dimer] (SGZ) $)_{2}$ have been synthesized and characterized through a rapid, simple, and efficient methodology in excellent yield. These compounds were screened for in vitro antibacterial activities against six pathogenic bacteria, such as Shigella sonnei, Escherichia coli, Bacilus subtilis, Sarcina lutea, Staphylococcus aureus and Pseudomonas arioginosa. The antibacterial activity was determined by the disc diffusion method using DMSO as solvent. The results indicate that (SGC) compound exhibit a significant antibacterial activity, depending on the bacterial strain and $(\mathrm{SGCo})_{2},(\mathrm{SGN})_{2}$ and $(\mathrm{SGZ})_{2}$ compounds show a moderate sensitivity even with higher doses. All these compounds were found to possess cytotoxic effect.
\end{abstract}

Keywords: Antibacterial activity; Schiff base transition metal complexes; minimum inhibitory concentration; Brine shrimp lethality

\section{INTRODUCTION}

During the last few decades, increased incidence of bacterial resistance to existing drugs has become a major concern throughout the world and necessitates continuing research into new classes of antibiotics ${ }^{1}$. Extensive use of antibacterial drugs and their resistance against bacterial infections has led to severe health problems. Of particular concern are severe infections caused by multidrug-resistant Gram-positive pathogens, such as Staphylococcus species $^{2,3}$, which has become a serious problem in hospitals and in the community. Resistance 
of wide spectrum antibacterial agents has prompted discovery and modification toward new chemical agents or antibiotics with a potent, wide therapeutic window, broad spectrum activity, and new mode of action.

The extensive investigations with a new antibacterial agents or metal complexes have been reported ${ }^{4-6}$. The advantages of such compounds are their diverse structural aspects viz. Metal, ligands, chelating agents having various functional groups and donor atoms capable of exerting selective toxicity. Consequently special attention has been given by researchers to schiff base complexes. Chohan et $\mathrm{al}^{7}$ studied the antimicrobial and toxicological activity of some mixed ligand transition metal complexes of Schiff bases. Ali et al ${ }^{8,9}$ showed that transition metal schiff base complexes are biologically active and possess pronounced anticancer properties. In the present paper, the antibacterial activities of four Schiff base complexes namely [N-salicylidene glycinato diaqua cobalt (II) dimer] (SGCo) $)_{2}, \quad[\mathrm{~N}$ salicylideneglycinato- di-aqua-nickel (11) dimer] (SGN) $)_{2}$ [N-salicylideneglycinato-aquacopper(II)] (SGC) and [N-salicylidene glycinato diaqua zinc(II) dimer] (SGZ) ${ }_{2}$ have been studied. In addition the cytotoxic effect and minimum inhibitory concentration (MIC) have also been evaluated.

\section{EXPERIMENTAL}

\section{1. General}

All the chemicals used throughout the research work were purchased from BDH (England) and used without further purification. Solvents were distilled prior to use.

All the reagents used were of commercial grade.

\section{2. General Procedure for the Preparation of the Schiff Base complexes}

The procedure was similar to that described elsewhere ${ }^{10-13}$. Alcoholic solutions of salicylaldehyde and glycine were mixed with saturated aqueous solution of metal acetates in 1:1:1 molar ratio. The whole mixture was refluxed for $2-3$ hours when crystalline product was obtained. The crystals were separated out from the mother liquor, recrystallized several times from alcoholic solution, dried in an oven at $50{ }^{\circ} \mathrm{C}$ and finally stored in a desiccator.

\section{3. Characterization of the complexes}

The synthesized compounds were characterized by IR spectra (as $\mathrm{KBr}$ disc by a Shimadzu FTIR, Japan) and the data obtained from elemental analysis for $\mathrm{C}, \mathrm{H}$ and $\mathrm{N}$ by using Perkin $240 \mathrm{C}$ analyzer and metals by atomic absorption spectrophotometer (Shimadzu, Japan). The weight loss for the coordinated water was determined by using DTA-TG analyzer (Mettler Instrument Corp. Highstown, NJ)

\section{4. Antibacterial Screening}

Antibacterial activities of the compounds were measured by observing the growth response of various microorganisms. The susceptibilities of such growth rate of microorganisms were measured in vitro by disc diffusion method ${ }^{14}$.

A loop full of the given test strain was inoculated in $30 \mathrm{ml}$ of nutrients broth and incubated for 24 hours in an incubator at $30^{\circ} \mathrm{C}$ in order to activate the bacterial strain activity. $20 \mathrm{ml}$ of the nutrients agar media was added in to $120 \mathrm{~mm}$ diameter petridishes. 
$0.1 \mathrm{ml}$ of the activated strain was inoculated into the media when it reached the temperature of $37^{\circ} \mathrm{C}$.

The media was allowed to solidify. After solidification of the media, a sterilized (BBL, Cocksrvile, U.S.A) filter paper disc (3 mm diameter) for sample and standard drug kanamycin $(30 \mu \mathrm{g} / \mathrm{disc})$ disc were taken in the petridishes. The test samples were applied on the disc with the help of a micropipette in an aseptic condition, controls were run (for each bacterial strain and each solvent), where pure solvent was applied on the disc in the petridishes. The petridishes were incubated for 24 hours at $37^{\circ} \mathrm{C}$.

The inhibition zone formed by the two compounds against the particular test bacterial strain determined the antibacterial activity of the synthetic complexes. Therefore, the diameter of zones showing complete inhibition $(\mathrm{mm})$ was measured and the growth inhibition was calculated with reference to positive control.

\section{4. 1. Preparation of stock solution of Test samples for antibacterial screening}

Exactly $3 \mathrm{mg}, 10 \mathrm{mg}$ and $20 \mathrm{mg}$ of SGC were dissolved separately in $1 \mathrm{ml}$ of DMSO to get concentration of 30, 100 and $200 \mu \mathrm{g} /$ disc respectively. Similarly $20 \mathrm{mg}, 40 \mathrm{mg}$ and $60 \mathrm{mg}$ of $(\mathrm{SGN})_{2}$ were dissolved separately in $1 \mathrm{ml}$ of DMSO to get concentration of 200, 400 and $600 \mu \mathrm{g} /$ disc respectively. Exactly $40 \mathrm{mg}, 60 \mathrm{mg}$ and $80 \mathrm{mg}$ of (SGZ) $)_{2}$ and (SGCo) 2 compounds were similarly dissolved in $1 \mathrm{ml}$ of DMSO to get concentration of 400, 600 and $800 \mu \mathrm{g} /$ disc respectively.

\section{5. Minimum Inhibitory Concentration (MIC)}

The MIC of the test compounds were determined by serial tube dilution technique ${ }^{15}$ against the same bacteria as used for antibacterial screening. Nutrient agar media was used for this purpose. Decreasing concentrations of test compounds were prepared in serial two fold dilution using the stock solution.

Bacterial suspension $(10 \mu \mathrm{l})$ containing $10^{7} \mathrm{cells} / \mathrm{ml}$ was inoculated into all tubes. After incubation for 24 hours at $37^{\circ} \mathrm{C}$, the test tube with no visible growth of the microorganism was taken to represent the MIC value of sample in $\mu \mathrm{g} / \mathrm{ml}$.

\section{6. Brine shrimp lethality bioassay}

The cytotoxic effect of the test compounds were studied by method as described by Attaur Rahman et $a l^{16}$. Brine shrimp (Artemia salina) eggs were hatched in artificial sea water (prepared by dissolving $38 \mathrm{~g} \mathrm{NaCl}$ in one liter distilled water) at room temperature under constant aeration for 48 hours.

Stock solutions of the complexes $(10 \mathrm{mg} / \mathrm{ml})$ in DMSO) were added to each vial, so that final concentration of the compounds became $0,20,40,60,80$ and $100 \mu \mathrm{g} / \mathrm{ml}$ after diluting them to $5 \mathrm{ml}$ with sea water.

To each vials, 10 living shrimps were added and allowed to stay there for 24 hours. The survived nauplii in each vial were counted and the results were noted. 


\section{RESULTS AND DISCUSSION}

\section{1. Synthesis}

The synthetic routes of metal complexes are outlined in the following Scheme I and Scheme II. Metal complexes were prepared by condensation of Salicylaldehyde and Glycine in ethanol in good yield.

SCHEME: I<smiles>O=Cc1ccccc1O</smiles>

Salicylaldehyde<smiles>NCC(=O)OCc1ccc([O-])c(C=NCC(=O)[O-])c1</smiles>

\section{SCHEME: II}<smiles>[O-]CCN=Cc1ccccc1[O-]</smiles>

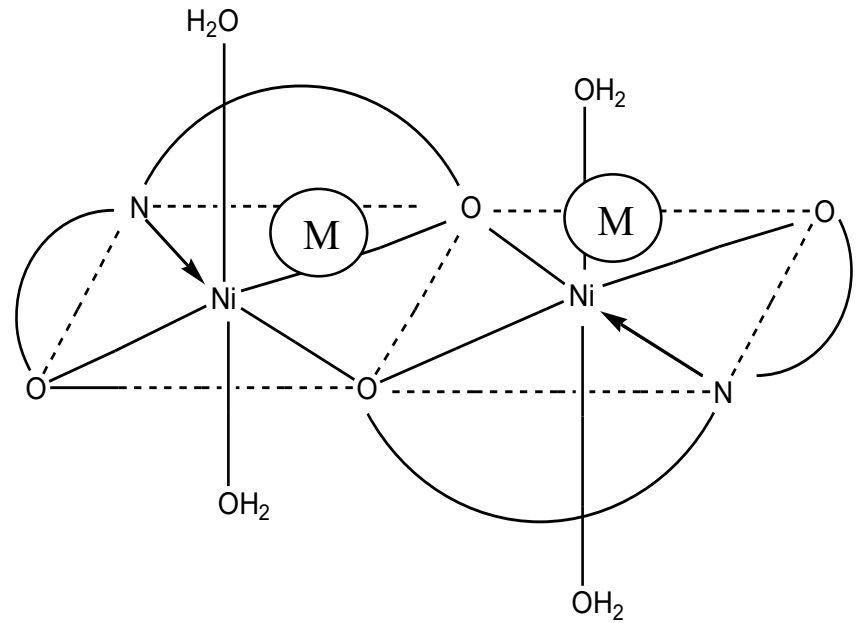

(a)

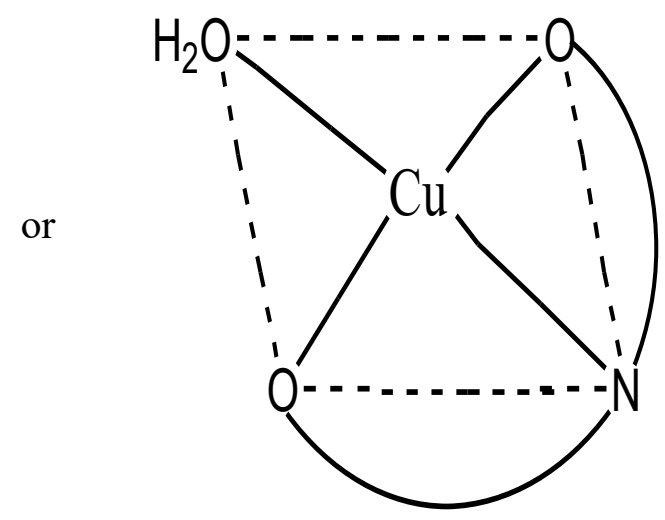

(b)

Figure 1. Structure of Schiff base complexes

(a) $\mathrm{M}=\mathrm{Ni}, \mathrm{Zn}$ or $\mathrm{Co}$, dimeric octahedral structure for $\mathrm{Ni}, \mathrm{Zn}$ and Co complexes

(b) Square planar structure for $\mathrm{Cu}$ complex 
Here, the skeleton -O-N-O- represents the following base ligand:

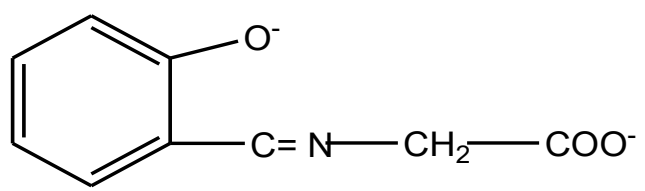

The purity of the final products have been verified with the help of IR spectral, elemental analytical data for the metals, carbon, hydrogen, and nitrogen content, which are in accordance with the structures shown in figure 1. The melting points of these compounds could not be measured owing to their thermal instability above $200{ }^{\circ} \mathrm{C}$ probably due to the loss of coordinated water and also the burning of organic part of the molecule. From the TGDTA thermogram (not shown here) the percentages of water content have been calculated corresponding to the weight loss owing to the endothermic effects between $200-220{ }^{\circ} \mathrm{C}$. For $(\mathrm{SGCo})_{2}(\mathrm{SGN})_{2},(\mathrm{SGC})$ and $(\mathrm{SGZ})_{2}$ these values were found to be $12.8 \%, 12.55 \%, 6.6 \%$ and $12.4 \%$ by weight respectively. These values were very much similar to those of the theoretical values for the coordinated water contents. All the data presented in table 1 is in good agreement with the molecular structure proposed earlier ${ }^{10-13}$.The complexes with nickel, zinc and cobalt were found to be dimeric and that with copper was monomeric.

Table 1. Physical and chemical analysis data.

\begin{tabular}{|c|c|c|c|c|c|}
\hline $\begin{array}{c}\text { Test } \\
\text { compound }\end{array}$ & $\begin{array}{c}\text { Yield } \\
\%\end{array}$ & $\begin{array}{l}\text { Physical } \\
\text { form }\end{array}$ & Solubility & $\begin{array}{c}\text { Elemental } \\
\text { analytical data, } \\
\%\end{array}$ & $\begin{array}{c}\text { IR spectra, } \\
\mathbf{c m}^{-1}\end{array}$ \\
\hline$(\mathrm{SGCo})_{2}$ & 50 & $\begin{array}{c}\text { Brown } \\
\text { crystalline }\end{array}$ & $\begin{array}{l}\text { Ethanol } \\
\text { Methanol } \\
\text { DMSO and } \\
\text { Acetone }\end{array}$ & $\begin{array}{c}\mathrm{C}=39.22(39.70) \\
\mathrm{O}=3.98(4.04) \\
\mathrm{H}=5.32(5.15) \\
\mathrm{Co}=21.57(21.69) \\
\mathrm{H}_{2} \mathrm{O}=12.78(13.23)\end{array}$ & $\begin{array}{c}1287 \mathrm{~s}(\mathrm{C}-\mathrm{N}) \\
1691-1598 \mathrm{w} \\
(\mathrm{C}=\mathrm{N}) \\
3516 \mathrm{~s}, 3442 \mathrm{~s} \\
3296 \mathrm{~s}(\mathrm{phenolic}- \\
\text { OH) } \\
563 \mathrm{~s}(\mathrm{Co}-\mathrm{N}) \\
500 \mathrm{~s}(\mathrm{Co}-\mathrm{O})\end{array}$ \\
\hline$(\mathrm{SGN})_{2}$ & 50 & $\begin{array}{l}\text { Greenish } \\
\text { yellow } \\
\text { crystal }\end{array}$ & $\begin{array}{l}\text { Ethanol } \\
\text { Methanol } \\
\text { DMSO and } \\
\text { Acetone }\end{array}$ & $\begin{array}{c}\mathrm{C}=37.17(39.75) \\
\mathrm{O}=4.01(4.04) \\
\mathrm{H}=5.26(5.10) \\
\mathrm{Ni}=20.96(21.60) \\
\mathrm{H}_{2} \mathrm{O}=12.55(13.25)\end{array}$ & $\begin{array}{c}3600 \mathrm{w}, 3400 \mathrm{w}(\mathrm{H}- \\
\left.{ }_{2} \mathrm{O}\right) \\
1640 \mathrm{~s}(\mathrm{C}=\mathrm{N}) \\
1307 \mathrm{sh}(\mathrm{C}-\mathrm{N}) \\
560 \mathrm{~s}(\mathrm{Ni}-\mathrm{N}) \\
487 \mathrm{~s}(\mathrm{Ni}-\mathrm{O})\end{array}$ \\
\hline
\end{tabular}




\begin{tabular}{|c|c|c|c|c|c|}
\hline (SGC) & 60 & $\begin{array}{l}\text { Black } \\
\text { crystal }\end{array}$ & $\begin{array}{l}\text { Ethanol } \\
\text { Methanol } \\
\text { DMSO and } \\
\text { Acetone }\end{array}$ & $\begin{array}{c}\mathrm{C}=41.55(41.93) \\
\mathrm{O}=3.06(3.11) \\
\mathrm{H}=5.24(5.44) \\
\mathrm{Cu}=24.33(24.67) \\
\mathrm{H}_{2} \mathrm{O}=6.55(6.98)\end{array}$ & $\begin{array}{c}1323 \mathrm{~s}, 1303 \mathrm{~s}(\mathrm{C}- \\
\mathrm{N}) \\
1629 \mathrm{~s}, 1602 \mathrm{~s} \\
(\mathrm{C}=\mathrm{N}) \\
3566 \mathrm{sh}, 3550 \mathrm{w} \\
\left(\mathrm{H}_{2} \mathrm{O}\right) \\
585-560 \mathrm{w}(\mathrm{Cu}-\mathrm{N}) \\
478 \mathrm{~s}(\mathrm{Cu}-\mathrm{O})\end{array}$ \\
\hline$(\mathrm{SGZ})_{2}$ & 50 & $\begin{array}{c}\text { White } \\
\text { crystalline }\end{array}$ & $\begin{array}{l}\text { Ethanol } \\
\text { Methanol } \\
\text { DMSO and } \\
\text { Acetone }\end{array}$ & $\begin{array}{c}\mathrm{C}=38.81(38.94) \\
\mathrm{O}=3.66(3.60) \\
\mathrm{H}=4.98(5.05) \\
\mathrm{Zn}=23.38(23.57) \\
\mathrm{H}_{2} \mathrm{O}=12.31(12.97)\end{array}$ & $\begin{array}{c}1287 \mathrm{~s}(\mathrm{C}-\mathrm{N}) \\
1612 \mathrm{~s}, 1575 \mathrm{~s}, \\
1541 \mathrm{~s}(\mathrm{C}=\mathrm{N}) \\
3313 \mathrm{~s} \text { (phenolic - } \\
\mathrm{OH})\end{array}$ \\
\hline
\end{tabular}

\section{2. Biological Activities}

The antibacterial activities of these complexes were measured in terms of zone of inhibition are shown in Table 2. The test compounds showed a good sensitivity against a number of pathogenic bacteria. The results were compared with standard drug disc of kanamycin $(30 \mu \mathrm{g} / \mathrm{disc})$.

Table 2. Results of antibacterial activities of the four compounds

\begin{tabular}{|c|c|c|c|c|c|c|c|c|c|c|c|c|c|c|c|}
\hline \multirow{3}{*}{\multicolumn{2}{|c|}{ 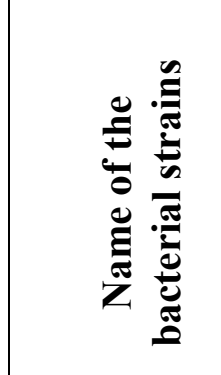 }} & \multicolumn{14}{|c|}{ Diameter of zone inhibition (mm) } \\
\hline & & \multicolumn{3}{|c|}{$(\mathrm{SGZ})_{2}, \mu \mathrm{g} / \mathrm{disc}$} & \multicolumn{3}{|c|}{$(\mathrm{SGCo})_{2}, \mu \mathrm{g} /$ disc } & \multicolumn{3}{|c|}{$(\mathrm{SGC}), \mu \mathrm{g} / \mathrm{disc}$} & \multicolumn{3}{|c|}{$(\mathrm{SGN})_{2}, \mu \mathrm{g} /$ disc } & \multirow{2}{*}{$\begin{array}{l}0 \\
\sum_{2}^{\infty} \\
0 \\
0 \\
0 \\
0 \\
0 \\
0\end{array}$} & \multirow{2}{*}{$\begin{array}{c}\text { Standard } \\
\text { Drug } \\
\text { (Kanamycin) } \\
30 \mu \mathrm{g} / \mathrm{disc}\end{array}$} \\
\hline & & 400 & 600 & 800 & 400 & 600 & 800 & 30 & 100 & 200 & 200 & 400 & 600 & & \\
\hline \multirow{2}{*}{ 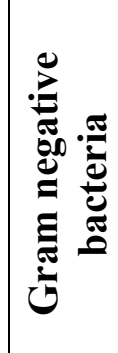 } & $\begin{array}{c}5 \\
\vdots \\
\vdots \\
\vdots \\
5\end{array}$ & 15 & 18 & 21 & 13 & 16 & 19 & 07 & 07 & 11 & 11 & 13 & 15 & 0 & 31 \\
\hline & $\underset{8}{8}$ & 9 & 11 & 15 & 7 & 10 & 14 & 10 & 13 & 15 & 13 & 18 & 22 & 0 & 30 \\
\hline
\end{tabular}




\begin{tabular}{|c|c|c|c|c|c|c|c|c|c|c|c|c|c|c|c|}
\hline & 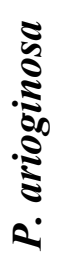 & 6 & 7 & 22 & 5 & 9 & 16 & $\mathrm{R}$ & 10 & 14 & $\mathrm{R}$ & $\mathrm{R}$ & $\mathrm{R}$ & 0 & 30 \\
\hline \multirow{3}{*}{ 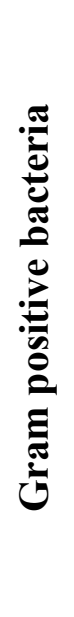 } & 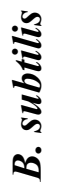 & 8 & 9 & 11 & 7 & 9 & 12 & - & - & - & - & - & - & 0 & 26 \\
\hline & $\frac{\mathbb{s}}{\mathbb{S}}$ & 8 & 9 & 10 & 6 & 8 & 9 & - & - & - & - & - & - & 0 & 25 \\
\hline & 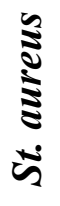 & 7 & 8 & 10 & 6 & 8 & 11 & 16 & 19 & 22 & $\mathrm{R}$ & $\mathrm{R}$ & $\mathrm{R}$ & 0 & 27 \\
\hline
\end{tabular}

$\mathrm{R}=$ Resistant and $(-)=$ Not done.

Potency of (SGC) against all test organisms was quite comparable with that of standard drug kanamycin at dose $30 \mu \mathrm{g} / \mathrm{disc}$. Somewhat better results were obtained when tested with higher doses $(100 \mu \mathrm{g} / \mathrm{disc}$ and $200 \mu \mathrm{g} / \mathrm{disc})$ of the complexes. Other three compounds $\left[(\mathrm{SGN})_{2},(\mathrm{SGCo})_{2}\right.$ and $\left.(\mathrm{SGZ})_{2}\right]$ showed moderate activity even at high doses. The solvent DMSO showed no activity against any bacterial strain. MIC values of the test compounds were determined as $\mu \mathrm{g} / \mathrm{ml}$ and are shown in Table 3 .

Table 3. Results of minimum inhibitory concentration of the four compounds

\begin{tabular}{|c|c|c|c|c|}
\hline \multirow{2}{*}{ Test organisms } & SGC & $\mathbf{( S G N}_{\mathbf{2}}$ & $\mathbf{( S G Z )}_{\mathbf{2}}$ & (SGCo) $_{\mathbf{2}}$ \\
\cline { 2 - 5 } & $\mathrm{MIC} \mu \mathrm{g} / \mathrm{ml}$ & $\mathrm{MIC} \mu \mathrm{g} / \mathrm{ml}$ & $\mathrm{MIC} \mu \mathrm{g} / \mathrm{ml}$ & $\mathrm{MIC} \mu \mathrm{g} / \mathrm{ml}$ \\
\hline St. aureus & 32 & 256 & 128 & 32 \\
\hline E. coli & 64 & 128 & 128 & 16 \\
\hline S. soneei & 32 & 128 & 64 & 32 \\
\hline P. aeruginosa & 128 & 512 & 128 & 128 \\
\hline
\end{tabular}


The brine shrimp lethality bioassay has been chosen to assess the in vitro cytotoxic effect of the test compounds. Median lethal concentration $\left(\mathrm{LC}_{50}\right)$ of brine shrimp lethality was measured from the plots of percentage of mortality versus concentration of the samples (Fig. 2). $\mathrm{LC}_{50}$ of $(\mathrm{SGN})_{2},(\mathrm{SGC}),(\mathrm{SGZ})_{2}$, and $(\mathrm{SGCo})_{2}$ were found to be $55.22,40,42$ and 32.5 $\mu \mathrm{g} / \mathrm{ml}$ respectively.

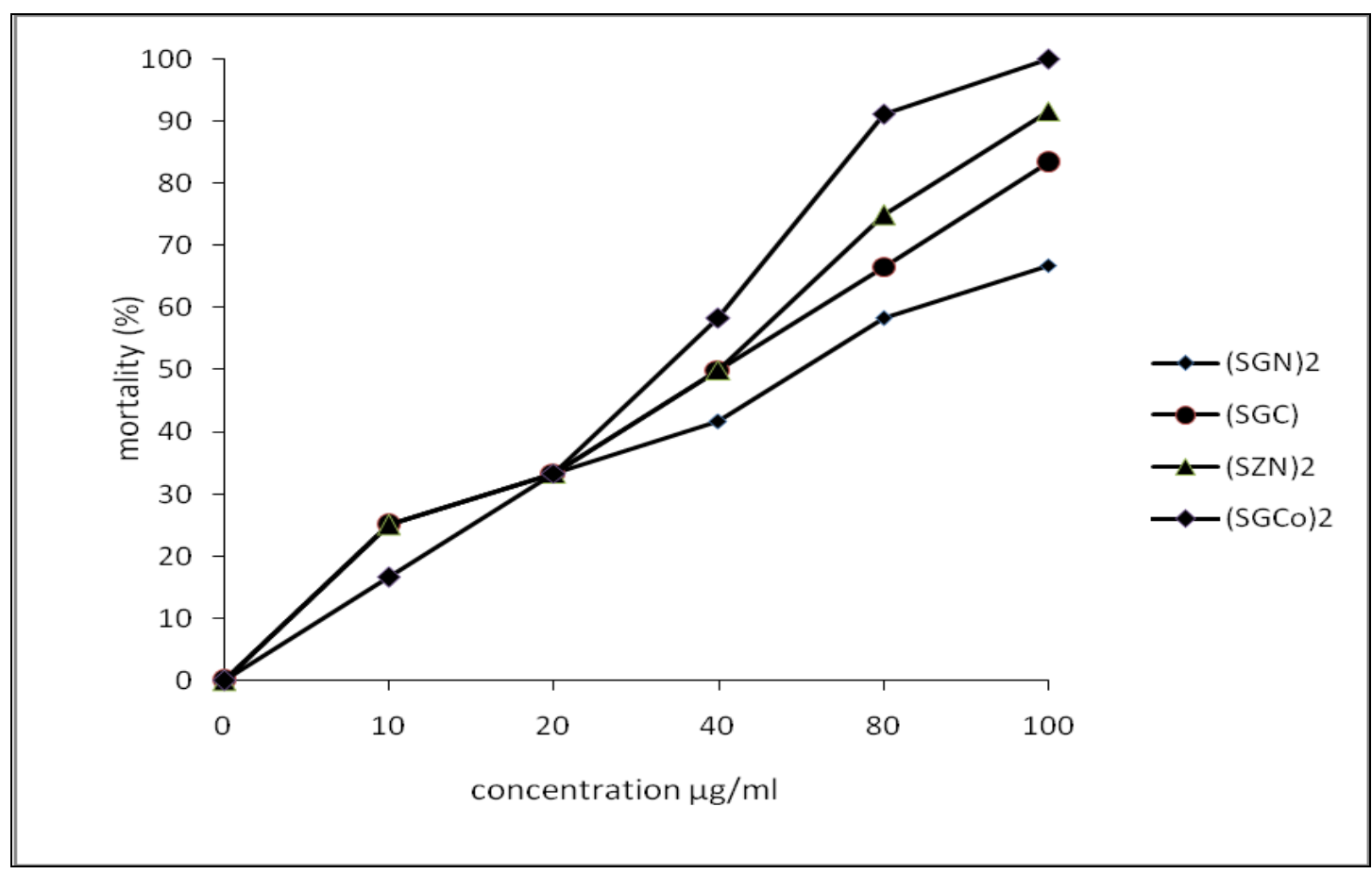

Figure 2. Brine shrimp lethality bioassay of the test compounds

From the results discussed above it is clear that the synthesized complexes are biologically active. Among the complexes studied SGC is the most efficient.

\section{CONCLUSIONS}

In conclusion, we have described simple, rapid and efficient protocol for the synthesis of a new series of four transition metal complexes of a schiff base derived from salicylaldehyde and glycine, viz. [N-salicylidene glycinato diaqua cobalt (II) dimer] (SGCo) ${ }_{2}$, [N- salicylideneglycinato- di-aqua-nickel (11) dimer] (SGN)2, [N-salicylideneglycinato-aquacopper(II)] (SGC) and [N-salicylidene glycinato diaqua zinc(II) dimer] (SGZ) $)_{2}$ with excellent yields. All the synthesized compounds have been investigated for their antibacterial activities. With our newly synthesized compounds, it is evident that (SGC) compound exhibit a significant antibacterial activity and $(\mathrm{SGCo})_{2},(\mathrm{SGN})_{2}$ and $(\mathrm{SGZ})_{2}$ compounds show a moderate sensitivity even with higher doses. All these compounds were found to possess cytotoxic effect. Therefore, these compounds may be used as new antibacterial drugs after performing further research works with advanced technology. 


\section{ACKNOWLEDGEMENT}

The authors are thankful to the authorities of the Institute of Biological Science (IBS), University of Rajshahi, Rajshahi-6205, Bangladesh for kindly providing pathogenic microorganisms.

\section{References}

[1] N. Woodford, Expert Opin. Invest. Drugs 12 (2003) 117-137.

[2] M. Khare, D. Keady, Expert Opin. On Pharmacother 4 (2003) 165-177.

[3] D. Adam, J. Antimicrob. Chemother. 50 (2002) 1-5.

[4] C. Sheikh, M. S. Hossain, M. S. Easmin, M. S. Islam, M. Rashid, Biol. Pharma. Bull. 27 (2004) 710-713.

[5] J. A. Khanam, M. F. Begum, J. Ara, M. Jesmin, M. A. Taher, M. M. Ali., Dhaka Univ. J. Pharm. Sci. 5 (2006) 29-32.

[6] M. R. Islam, S. M. Islam, A. S. M. Noman, J. A. Khanam, M. M. Ali, S. Alam, M. W. Lee., Mycobiology 35(2007) 25-29.

[7] Z. H. Chohan, M. Arif, Z. Shafiq, M. Yaqub, C. T. Supuram, J. Enzyme Inhib. Med. Chem. 21 (2006) 95-103.

[8] M. M. Ali, M. Jesmin, M. K Sarker, M. S. Salahuddin, M. R. Habib, J. A. Khanam., Int. J. Biol. Chem. Sci. 2 (2008) 292-298.

[9] M. M. Ali, M. Jesmin, M. N. Islam, S. M. S. Shariar, M. R. Habib, M. F. Islam, J. A. Khanam., ACGC Chem. Res. Comm. 23 (2009) 13-22.

[10] R. Pani and B. Behera., Ind. J. Chem. 12 (1974) 215-216.

[11] R. K. Ray and G. B. Kauffman., J. Ther. Anal. Cal. 35 (1989) 1603-1609.

[12] A. Nakahara., Bull. Chem. Soc. Japan. 22 (1959) 1195.

[13] L. J. Theriot, G. O. Carlisle, H. J. Hu, J. Inorg. Chem. 31 (1969) 2891.

[14] A. W. Bauer, W. M. M. Kirby, J. C. Sherries, M. Truck, Am. J. Clin. Path. 44 (1966) 493-497.

[15] E. Jawetz, J. L. Melnick, E. A. Adelberg., Lange, Medical Pub. $14^{\text {th }}$ ed., California, 1980, p. 123-124.

[16] Atta-ur-Rahman, M. I. Choudhary, W. J. Thomsen., Harwood Academic Press, Amsterdam, 1999, p. 12-22. 